\title{
Butterflies (Lepidoptera: Papilionoidea and Hesperioidea) of the Parque Ecológico João Vasconcelos Sobrinho, Caruaru, Pernambuco, Brazil
}

\author{
Márlon Paluch ${ }^{1,6}$, Olaf Hermann Hendrik Mielke ${ }^{2}$, Carlos Eduardo Beserra Nobre ${ }^{3}$, \\ Mirna Martins Casagrande 2 , Douglas Henrique Alves Melo ${ }^{4}$ \& André Victor Lucci Freitas 5 \\ ${ }^{1}$ Centro de Ciências Agrárias Ambientais e Biológicas, Universidade Federal do Recôncavo da Bahia - UFRB, \\ Rua Rui Barbosa, 710, Campus Universitário, CEP 44380-000, Cruz das Almas, BA, Brazil \\ ${ }^{2}$ Departamento de Zoologia, Centro Politécnico, Universidade Federal do Paraná - UFPR, \\ CP 19020, CEP 81531-980, Curitiba, PR, Brazil \\ ${ }^{3}$ Departamento de Botânica, Universidade Federal de Pernambuco - UFPE, \\ Av. Prof. Moraes Rego, 1235, Cidade Universitária, CEP 50670-901, Recife, PE, Brazil \\ ${ }^{4}$ Universidade Federal Rural de Pernambuco - UFPE, \\ Rua Dom Manoel de Medeiros, s/n, Dois Irmãos, CEP 52171-900, Recife, PE, Brazil \\ ${ }^{5}$ Departamento de Biologia Animal and Museu de História Natural, Instituto de Biologia, \\ Universidade Estadual de Campinas - UNICAMP, \\ Cidade Universitária Zeferino Vaz, Rua Monteiro Lobato, 255, CP 6109, CEP 13083-970, Campinas, SP, Brazil \\ ${ }^{6}$ Corresponding author: Márlon Paluch,e-mail: marlonpaluch@gmail.com
}

PALUCH, M., MIELKE, O.H.H., NOBRE, C.E.B., CASAGRANDE, M.M., MELO, D.H.A. \& FREITAS, A.V.L. Butterflies (Lepidoptera: Papilionoidea and Hesperioidea) of the Parque Ecológico João Vasconcelos Sobrinho, Caruaru, Pernambuco, Brazil. Biota Neotrop. 11(4): http://www.biotaneotropica.org.br/v11n4/en/ abstract?inventory+bn01911042011

\begin{abstract}
Comprising a natural reserve with 359 ha of "montane forest" inserted on the Brazilian semi-arid, the Parque Ecológico João Vasconcelos Sobrinho (PEJVS), locally known as "Brejo dos Cavalos" is currently under high anthropogenic pressure. A list of 197 species of butterflies belonging to six families is presented, being 59 species of Hesperiidae, 4 of Papilionidae, 18 of Pieridae, 17 of Lycaenidae, 12 of Riodinidae and 87 of Nymphalidae. The butterfly community was composed mainly by widespread species commonly found in open habitats. There were also many species typical of forested areas such as Scada karschina delicata Talbot, 1932 (Danainae: Ithomiini), which is an endangered butterfly.

Keywords: inventory, conservation, species richness, semi-arid vegetation.
\end{abstract}

PALUCH, M., MIELKE, O.H.H., NOBRE, C.E.B., CASAGRANDE, M.M., MELO, D.H.A. \& FREITAS, A.V.L. As borboletas (Lepidoptera: Papilionoidea e Hesperioidea) do Parque Ecológico João Vasconcelos Sobrinho, Caruaru, Pernambuco, Brasil. Biota Neotrop. 11(4): http://www.biotaneotropica.org.br/v11n4/pt/ abstract?inventory+bn01911042011

Resumo: O Parque Ecológico João Vasconcelos Sobrinho (PEJVS), conhecido localmente como Brejo dos Cavalos, é um fragmento de "mata serrana" de 359 ha inserido no semi-árido brasileiro, e que atualmente encontra-se sobre alta pressão antrópica. Uma lista com 197 espécies de borboletas pertencentes a seis famílias é apresentada, sendo 59 espécies de Hesperiidae, 4 de Papilionidae, 18 de Pieridae, 17 de Lycaenidae, 12 de Riodinidae e 87 de Nymphalidae. A fauna é composta principalmente de espécies de áreas abertas e com ampla distribuição geográfica. Entretanto, diversas espécies típicas de áreas florestadas também estão presentes, uma delas, Scada karschina delicata Talbot, 1932 (Danainae: Ithomiini), é uma espécie de borboleta criticamente ameaçada de extinção.

Palavras-chave: inventário, conservação, riqueza de espécies, semi-árido. 


\section{Introduction}

The butterfly fauna of Northeastern Brazil remains largely unknown (Santos et al. 2008), and except for some recent published inventories (Garcia et al. 1990, Nobre et al. 2008, Vasconcelos et al. 2009), most available lists are quite old (Bates 1867, Rocha 1908, 1936, 1954, May 1924, D’ Almeida 1935, Cardoso 1949, Alvarenga 1962, Kesselring \& Ebert 1982). Of the above papers, three of them are complete enough to provide a reasonable picture of the butterfly assemblages of Northeastern Brazil. Two of these inventories were carried out in humid areas of Atlantic Forest for more than five years. Cardoso (1949) reported 218 species of butterflies in urban areas of Maceió, state of Alagoas. Additionally, Kesselring \& Ebert (1982) surveyed an urban fragment in João Pessoa, state of Paraíba, and recorded 291 species. The first published inventory on the butterfly community of the northeastern semi-arid revealed a richness of 121 species from the Parque Nacional do Catimbau (PNC), state of Pernambuco, Brazil (Nobre et al. 2008).

The semi-arid region of Brazil is one of the poorest known biomes concerning butterflies (Santos et al. 2008). It includes several sites of humid forests, locally known as "brejos", along the windward slopes of some plateaus and mountains above $500 \mathrm{~m}$, receiving more than $1200 \mathrm{~mm}$ of annual rainfall (Andrade-Lima 1982, Prado 2003). These humid forests are of extreme biological relevance and are considered priority for conservation (Tabarelli \& Santos 2004). For example, some of these "brejos" harbor the last known populations of threatened butterfly species from Northeastern Brazil: the endangered Morpho (Grasseia) menelaus eberti Fischer, 1962 and Morpho (Pessonia) epistrophus nikolajewna Weber, 1951 (Nymphalidae: Satyrinae: Morphini), and the critically endangered Scada karschina delicata Talbot, 1932 (Nymphalidae: Danainae: Ithomiini) (Machado et al. 2008, Freitas \& Marini-Filho 2011).

The Parque Ecológico João Vasconcelos Sobrinho (PEJVS), also known as "Brejo dos Cavalos", has one of the most important "brejos" areas in the semi-arid of Pernambuco (Braga et al. 2002). Although the PEJVS is a protected area, this park is nonetheless impacted by human activities, such as the replacement of forest areas for irrigated agriculture of Sechium edule (Jacq.) Sw (Cucurbitaceae) (the chayote) that increases the consumption of water resources, in addition to clay and silt exploitation (Braga et al. 2002, Cabral et al. 2004). In this context, the present paper provides the first list of butterflies recorded in the PEJVS. It is expected that this list may offer subsidies for future conservation strategies in a region with accelerated destruction.

\section{Material and Methods}

The study was conducted in the PEJVS, located in Serra dos Cavalos, municipality of Caruaru, State of Pernambuco ( $8^{\circ} 22^{\prime} 09^{\prime \prime} \mathrm{S}$, $36^{\circ} 05^{\prime} 00^{\prime \prime} \mathrm{W}$ ) (Figure 1). The PEJVS has 359 ha and is part of the altitude wetlands of the states of Pernambuco and Paraíba. It consists of scattered montane semideciduous forests in a semi-arid region comprised within the Brazilian Atlantic Forest domain (Braga et al. 2002, Cabral et al. 2004, Tabarelli \& Santos 2004).

The PEJVS is an example of environmental protection in the region, representing one of the most significant remnants of Atlantic Forest in the state of Pernambuco. The area comprises three major reservoirs used for human consumption (Braga et al. 2002, Cabral et al. 2004). The locality chosen for the butterfly inventory is a well-preserved forest fragment with an altitude of approximately $840 \mathrm{~m}$, and it is located between the two largest dams of the park (8²1' 45.36” S, 3602'11.31' W).

Butterflies were sampled between September to December 2007 and 2008 (dry season), and between February to May 2011 (wet season), totaling 12 field trips. Fieldwork was conducted from 9:00 AM to 3:00 PM, during three days per month, with a total sampling effort of 216 hours. The samplings were carried out by one or two person along all habitats. The butterflies were caught with entomological nets and 10 traps baited with a fermented mixture of banana and sugar cane juice placed in forest gaps.

The collected material is deposited at the entomological collections of the following institutions: Universidade Federal de Pernambuco, Recife, and Universidade Federal do Paraná, Curitiba, Brazil. Nomenclature follows Lamas (2004), except for the suprageneric categories of Nymphalidae modified after Wahlberg et al. (2009).

\section{Results and Discussion}

A total of 197 butterfly species were recorded in the PEJVS. Of these, 138 (70\%) were in the Papilionoidea and $59(30 \%)$ in the Hesperioidea, with the following distribution: Hesperiidae (59 spp., $30 \%$ of the total), Papilionidae (4 spp., $2 \%$ ), Pieridae (18 spp., 9\%), Lycaenidae (17 spp., 9\%), Riodinidae (12 spp., 6\%), and Nymphalidae (87 spp., 44\%) (Appendix 1). The butterfly fauna was dominated by species commonly found in open areas and widely distributed in Brazil, but also includes species more frequent in humid forests.

The tribe Ithomiini (Danainae) was represented by 14 species, and includes some species typical of closed humid forests, such
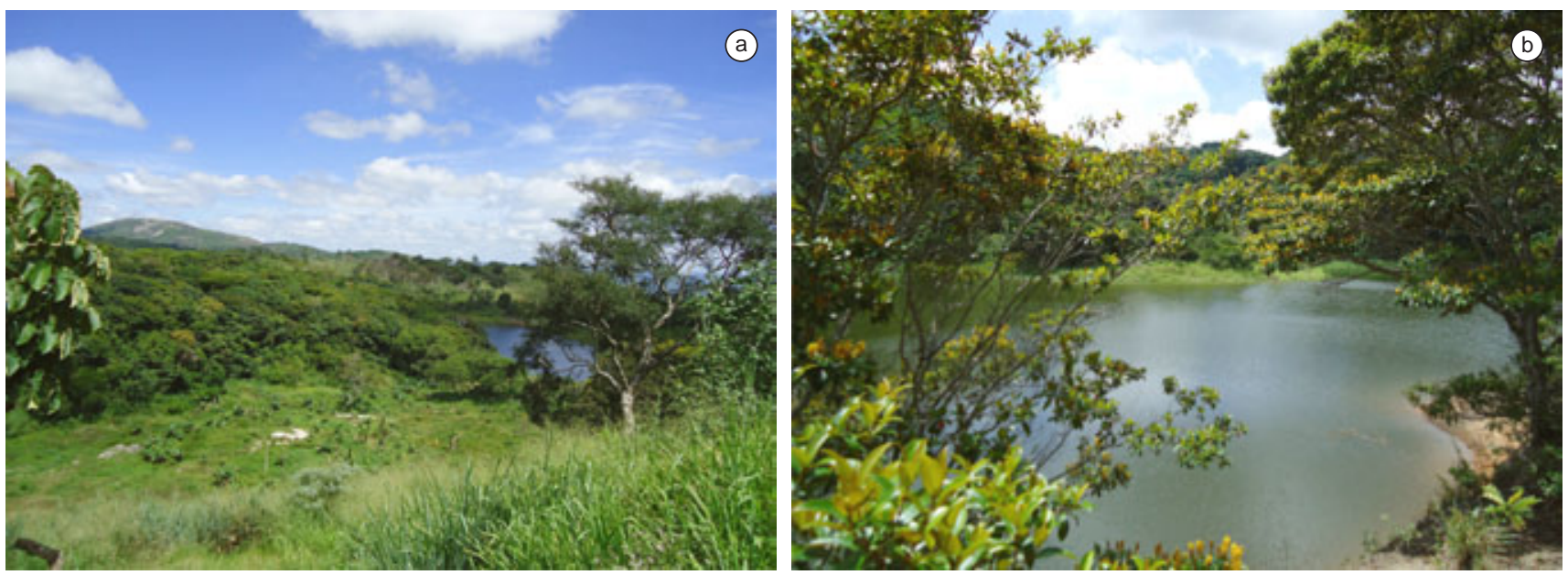

Figure 1. Two views of the "Parque Ecológico João Vasconcelos Sobrinho". Top, general view of the study area showing the different vegetal formations; bottom, close view of the habitats nearby an artificial lake (Açude Guilherme de Azevedo). 
as the clearwings Pseudoscada erruca (Hewitson, 1855) and Heterosais edessa (Hewitson, [1855]), the yellow transparent Napeogenes inachia ssp. and the critically endangered Scada karschina delicata Talbot, 1932 (Freitas \& Brown Junior 2008), abundant and locally common in February 2006 at the Frei Caneca Particular Reserve, Jaqueira, Pernambuco. Although the butterfly fauna of the PEJVS is dominated by widespread species of secondary habitats, the study site is one of the few places where the critically endangered ithomiine $S$. karschina delicata can be found. Four specimens were recorded between September and October 2007, with an additional specimen found in the collection of the Universidade Federal de Pernambuco. This subspecies is endemic to Pernambuco (sensu Brown Junior 1979, 1987), and until recently it was known only from a single locality near the border of the states of Pernambuco and Paraiba (Brown Junior 1979). With the present record, this increases to six the number of localities where this taxon is present (see also Freitas 2003, 2004, Freitas \& Brown Junior 2005, 2008, Machado et al. 2008), increasing the opportunities for conservation of this butterfly.

Heliconiinae was represented by eight taxa of wide distribution in all Atlantic Forest, and by two endemic taxa to the forests of Northeastern Brazil, namely Heliconius ethilla flavomaculatus Weymer, 1894 (Heliconiini) and Actinote pellenea aulodea Oberthür, 1917 (Acraeini). The record of the latter is quite interesting since this taxon has not been reported after 1971, from the municipality of Paulista, Pernambuco (Paluch 2006). The present study recorded a vigorous population of A. pellenea aulodea in the study site, with the adults flying between October and November.

Only seven common species of the tribes Morphini and Brassolini were recorded in the study site. The endangered Morpho menelaus eberti was not found in PEJVS, but additional efforts are necessary, mainly in fall and winter, to confirm whether the species occur or not locally. The subspecies was very common in February 2006 at the RPPN Frei Caneca, Jaqueira, Pernambuco. It probably has only one generation each year (O. Mielke, pers. obs.). Morpho (Morpho) helenor anakreon Fruhstorfer, 1910 was common in the area between September and February.

All remaining Nymphalidae subfamilies were represented by species widely distributed in different Brazilian Biomes (from South Brazil to Amazonian borders). However, additional efforts may reveal a richer fauna of Nymphalidae, especially in the tribe Satyrini (Satyrinae), and in the genus Adelpha Hübner, [1819] (Limenitidinae).

Only four species of Papilionidae were recorded. Three of them were already expected for the area: Heraclides anchisiades capys (Hübner, [1809]), Heraclides thoas brasiliensis (Rothschild \& Jordan, 1906) and Battus polydamas polydamas (Linnaeus, 1758), because they are very common and occur throughout the Brazilian coast (Tyler et al. 1994), and also in the Caatinga (Nobre et al. 2008). However, the occurrence of Parides zacynthus polymetus (Godart, $1819)$ in the area was remarkable. In all its known distribution, P. zacynthus (Fabricius, 1793) is restricted to the coastal plains (in the "restingas" and lowland forests), not being known to occur in the countryside forests (Tyler et al. 1994). The presence of this butterfly in the study site can be considered relictual, and shows the importance of monitoring populations of Atlantic Forest species in the interior of the semi-arid domain (about $100 \mathrm{~km}$ far from the coast). Similarly, in two other localities of northeastern Brazil, Lençóis, Bahia $(300 \mathrm{~km}$ far from the coast) and Cruz do Espírito Santo, Paraíba (30 km far from the coast), P. zacynhus may be moving towards countryside habitats (O. Mielke pers. obs.).

Of the 18 recorded Pieridae, most of them are typical of open secondary forests, grasslands and more disturbed areas (Brown Junior 1992). Only Leucidia elvina (Godart,
1819) (Coliadinae), Dismorphia amphione astynome (Dalman, 1823), and Enantia lina versicolora (Fruhstorfer, 1912) (Dismorphiinae) were collected in transects inside the forest. The presence of two sympatric subspecies of Melete lycimnia (Cramer, 1777) (Pierinae: Pierini) reveals an unusual taxonomic situation. The two subspecies were observed flying at the same time in the PEJVS (also observed by OHHM and MMC on 8-II-2006 at the same locality). The event can only be elucidated by a review on the status of all 16 subspecies (Lamas 2004).

The Hesperiidae and Lycaenidae were undersampled, and we predict that these two families could be represented by twice as many species as recorded here. Typically, Hesperiidae is the dominant family in most well sampled Brazilian sites (Mielke 1995, Brown Junior 2005, Morais et al. 2007, Francini et al. 2011). In the present study, Nymphalidae was the richest family, suggesting that additional efforts may reveal a different structure for the butterfly assemblage of this area. This apparently bias towards Nymphalidae could be easily noted by considering the low species richness for Hesperiidae in the list, much lower than the numbers reported for other forest sites in Northeastern Brazil (Cardoso 1949, Kesselring \& Ebert 1982).

Considering Nymphalidae as a surrogate (25-29\%) of the total butterfly fauna (Brown Junior \& Freitas 2000), the total richness in the area could reach 290 to 350 species, which is higher than that recorded for Maceió (218 species), and equivalent to the total richness of João Pessoa (291) (Cardoso 1949, Kesselring \& Ebert 1982, Brown Junior \& Freitas 2000).

\section{Conservation perspectives}

The area of the PEJVS is important not only for being part of a system of vanishing wet forests of the semi-arid region, but also because it is one of the few remnants of Atlantic Forest in Northeastern Brazil, a region with more than $95 \%$ of its original vegetation destroyed by human activities (Galindo-Leal \& Câmara 2003, Tabarelli et al. 2005). Different approaches for conservation of the "brejos" ecosystems (e.g. PEJVS) have been proposed/ presented in recent publications, including public policies and local economy (Braga 2004, Theulen 2004, Tabarelli \& Santos 2004). Conservation strategies should be developed in conjunction with public entities, such as the Environment Secretariat of Caruaru, and non-governmental organizations responsible by the PEJVS. Priority actions for the PEJVS should include the proposition of a sustainable management plan focused on rehabilitation of degraded areas, including ecological monitoring and management of the surrounding environments so the area can keep sustaining health forests in the next decades.

\section{Acknowledgements}

We thank Dr. Angela Maria Isidro de Farias for the support and encouragement, and Marcelo Duarte da Silva from the Museu de Zoologia, Universidade de São Paulo, for the identification of Lycaenidae species. Cristiano Agra Iserhard, Lucas Augusto Kaminski, Blanca Huertas, Eduardo O. Emery and Carla Penz greatly improved the final version of the manuscript. Cristiano Agra Iserhard, Lucas Augusto Kaminski and Fernando M. S. Dias also helped with identifications of Charaxinae, Biblidinae, Riodinidae and Lycaenidae. The Environment Secretariat of Caruaru Municipality, PE granted a license for butterflies' collection in PEJVS. MP thanks CNPq/ FACEPE for scholarship aid (DCR - 0045-2.04/06) and FACEPE by the research project (APQ - 0011-2.04/07); OHHM and MMC to the CNPq for the fellowships; AVLF acknowledges the FAPESP (grants \#00/01484-1 and \#04/05269-9), the CNPq (fellowship 
\#300282/2008-7), and the National Science Foundation (DEB grant \#0527441). This publication is part of the RedLep "Rede Nacional de Pesquisa e Conservação de Lepidópteros" SISBIOTA-Brasil/ CNPq (563332/2010-7).

\section{References}

ALVARENGA, M. 1962. A entomofauna do arquipélago de Fernando de Noronha, Brasil - I. Arq. Mus. Nac. 52:21-25.

ANDRADE-LIMA, D. 1982. Present-day Forest refuges in northeastern Brazil. In Biological diversification in the tropics (G.T. Prance, ed.). Columbia University Press, New York, p.245-251.

BATES, H.W. 1867. On a collection of butterflies formed by Thomas Belt, Esq., in the interior of the province of Maranhão, Brazil. Trans. Entomol. Soc. London 5(7):535-546.

BRAGA, R.A.P., CABRAL, J.J.S.P., MONTENEGRO, S.M.G.L. \& PERRIER JUNIOR, G.S. 2002. Conservação dos recursos hídricos em brejos de altitude: O caso de Brejo dos Cavalos, Caruaru, PE. Rev. Bras. Eng. Agric. Ambiente. 6(3):539-546. http://dx.doi.org/10.1590/S141543662002000300028

BRAGA, E.C. 2004. Educação ambiental como estratégia para conservação do ecossistema dos brejos de altitude. In Brejos de Altitude em Pernambuco e Paraíba. História Natural, Ecologia e Conservação (K.C. Pôrto, J.J.P. Cabral \& M. Tabarelli, orgs.). Ministério do Meio Ambiente, Brasília, p.303-308

BROWN JUNIOR, K.S. 1979. Ecologia geográfica e evolução nas florestas neotropicais. Universidade Estadual de Campinas, São Paulo.

BROWN JUNIOR, K.S. 1987. Biogeography and evolution of neotropical butterflies. In Biogeography and Quaternary History in Tropical America (T.C. Whitmore \& G.T. Prance, eds.). Clarendon Press, Oxford, p.66-104.

BROWN JUNIOR, K.S. 1992. Borboletas da Serra do Japi: diversidade, hábitats, recursos alimentares e variação temporal. In História Natural da Serra do Japi - Ecologia e preservação de uma área florestal no Sudeste do Brasil (L.P.C. Morellato, ed.). Editora da Unicamp, Campinas, p.142-187.

BROWN JUNIOR, K.S. 2005. Geologic, evolutionary and ecological bases of the diversification of Neotropical butterflies: implications for conservation. In Tropical rainforests: Past, Present and Future (E. Bermingham, C.W. Dick \& C. Moritz, eds.). Chicago, University of Chicago Press, p.166-201.

BROWN JUNIOR, K.S. \& FREITAS, A.V.L. 2000. Atlantic Forest butterflies: indicators for landscape conservation. Biotropica 32:934-956.

CABRAL, J.J.P., BRAGA, R., MONTENEGRO, S., CAMPELLO, S., CIRILLO, A., PÉRRIER JUNIOR, G. \& LOPES FILHO, S. 2004. Recursos hídricos e os brejos de altitude. In Brejos de Altitude em Pernambuco e Paraíba. História Natural, Ecologia e Conservação (K.C. Pôrto, J.J.P. Cabral \& M. Tabarelli, orgs.). Ministério do Meio Ambiente, Brasília, p.31-48.

CARDOSO, A. 1949. Lepidópteros de Alagoas. Rev. Entomol. 20(1-3):427436.

D'ALMEIDA, R.F. 1935. Lista dos lepidópteros capturados pelo Dr. R.V. Ihering no nordeste do Brasil. Rev. Entomol. 5(3):326-328.

FRANCINI, R.B., DUARTE, M., MIELKE, O.H.H., CALDAS, A. \& FREITAS, A.V.L. 2011. Butterflies (Lepidoptera, Papilionoidea and Hesperioidea) of the "Baixada Santista" region, coastal São Paulo, Southeastern Brazil. Rev. Bras. Entomol. 55:55-68. http://dx.doi. org/10.1590/S0085-56262011000100010

FREITAS, A.V.L. 2003. Lista preliminar das espécies de borboletas na Usina Serra Grande, AL. http://www.cepan.org.br (último acesso em 12/2011).

FREITAS, A.V.L. 2004. Lista preliminar das espécies de borboletas na RPPN Frei Caneca, Jaqueira, PE. http://www.cepan.org.br (último acesso em 12/2011).

FREITAS, A.V.L. \& BROWN JUNIOR, K.S. 2005. Immature stages of Napeogenes sulphurina Bates, 1862 (Lepidoptera, Nymphalidae, Ithomiinae) from Northeastern Brazil. J. Lepid. Soc. 59(1):35-37.

FREITAS, A.V.L. \& BROWN JUNIOR, K.S. 2008. Scada karschina delicata Talbot, 1932. In Livro vermelho da fauna brasileira ameaçada de extinção (A.B.M. Machado, G.M.M. Drummond \& A.P. Paglia, eds.). MMA, Brasília; Fundação Biodiversitas, Belo Horizonte, p.403-404.
FREITAS, A. V. L. \& MARINI-FILHO, O. J. 2011. Plano de Ação Nacional para Conservação dos Lepidópteros Ameaçados de Extinção. ICMBio, Brasília, 124p.

GALINDO-LEAL, C. \& CÂMARA, I.G. 2003. Atlantic forest hotspots status: an overview. In The Atlantic Forest of South America: biodiversity status, threats, and outlook (C. Galindo-Leal \& I.G. Câmara, eds.). Center for Applied Biodiversity Science e Island Press, Washington, p.3-11.

GARCIA, I.P., BERGMANN, E.C. \& RODRIGUES, S.M. 1990. Diversidade mensal de borboletas na ilha de São Luis (MA). Arq. Inst. Biol. 57(1):39-44.

KESSELRING, J. \& EBERT, H. 1982. Relação das borboletas encontradas na "Mata do Buraquinho", João Pessoa, estado da Paraíba, Brasil. Rev. Nordest. Biol. 2(1):105-108.

LAMAS, G., ed. 2004. Checklist: Part 4A Hesperioidea - Papilionoidea. In Atlas of Neotropical Lepidoptera (J.B. Heppner, ed.) Association of Tropical Lepidoptera, Gainesville, 439p.

MACHADO, A.B.M., DRUMMOND, G.M.M. \& PAGLIA A.P. 2008. Livro vermelho da fauna brasileira ameaçada de extinção. MMA, Brasília; Fundação Biodiversitas, Belo Horizonte, 427p.

MAY, E. 1924. Relatório das excursões effectuadas nos estados de Rio, Minas Geraes e Bahia. Bol. Mus. Nac. 1(5):367-375.

MIELKE, C.G.C., 1995. Papilionoidea e Hesperioidea (Lepidoptera) de Curitiba e seus arredores, Paraná, com notas taxonômicas sobre Hesperiidae. Rev. Bras. Zool. 11(4):759-776. http://dx.doi.org/10.1590/ S0101-81751994000400018

MORAIS, A.B.B., ROMANOWSKI, H.P., ISERHARD, C.A., MARCHIORI, O. \& SEGUI, R. 2007. Mariposas del Sur de Sudamerica. Cienc. Ambient. 35:29-46.

NOBRE, C.E.B, SCHLINDWEIN, C. \& MIELKE, O.H.H. 2008. The butterflies (Lepidoptera: Papilionoidea and Hesperioidea) of the Catimbau National Park, Pernambuco, Brazil. Zootaxa 1751:35-45.

PALUCH, M. 2006. Revisão das espécies de Actinote Hübner, [1819] (Lepidoptera, Nymphalidae, Heliconiinae, Acraeini). Tese de Doutorado, Universidade Federal do Paraná, Curitiba.

PRADO, D.E. 2003. As caatingas da América do Sul. In Ecologia e conservação da Caatinga (I.R. Leal, M. Tabarelli \& J.M.C. Silva, eds.). Editora Universitária UFPE, Recife, p.3-73.

ROCHA, F.D. 1908. Insectos. Bol. Muz. Rocha 1(1):61-81.

ROCHA, F.D. 1936. Subsídios para o estudo da fauna cearense. Nord. Agrícola 1(1):28-32.

ROCHA, F.D. 1954. Subsídio para o estudo da fauna cearense. Rev. Inst. Ceara 58:185-204.

SANTOS, E.C., MIELKE, O.H.H. \& CASAGRANDE, M.M. 2008. Inventários de borboletas no Brasil: Estado da arte e modelo de áreas prioritárias para pesquisa com vista à conservação. Nat. Conserv. 6(2):68-90.

TABARELLI, M. \& SANTOS, A.M. 2004. Uma breve descrição sobre a história natural dos brejos Nordestinos. In Brejos de Altitude em Pernambuco e Paraíba. História Natural, Ecologia e Conservação (K.C. Pôrto, J.J.P. Cabral \& M. Tabarelli, orgs.). Ministério do Meio Ambiente, Brasília, p.17-24.

TABARELLI, M., PINTO, L.P., SILVA, M.C., HIROTA, M. \& BEDÊ, L. 2005. Challenges and opportunities for biodiversity conservation in the Brazilian Atlantic Forest. Conserv. Biol. 19:695-700. http://dx.doi. org/10.1111/j.1523-1739.2005.00694

THEULEN, V. 2004. Conservação e manejo dos brejos de altitude no estado de Pernambuco. In Brejos de Altitude em Pernambuco e Paraíba. História Natural, Ecologia e Conservação (K.C. Pôrto, Cabral \& M. Tabarelli, orgs.). Ministério do Meio Ambiente, Brasília, p.299-302.

TYLER, H., BROWN JUNIOR, K.S. \& WILSON, K. 1994. Swallowtail butterflies of the Americas: a study in biological dynamics, ecological diversity, biosystematics and conservation. Scientific Publishers, Gainesville, 376p.

VASCONCELOS, R.N., BARBOSA, E.C.C. \& PERES, M.C.L. 2009. Borboletas do Parque Metropolitano de Pituaçu, Salvador, Bahia, Brasil. Sitientibus. Ser. Cienc. biol. 9(2):158-164.

WAHLBERG, N., LENEVEU, J., KODANDARAMAIAH, U., PEÑA, C., NYLIN, S., FREITAS, A.V.L. \& BROWER, A.V.Z. 2009. Nymphalid butterflies diversify following near demise at the Cretaceous/ Tertiary boundary. Proc. R. Soc. B 276:4295-4302. PMid:19793750. PMCid:2817107. http://dx.doi.org/10.1098/rspb.2009.1303 


\section{Appendix}

Appendix I. Butterflies (Papilionoidea and Hesperioidea) from the "Parque Ecológico João Vasconcelos Sobrinho", Caruaru, Pernambuco, Brazil. Number of species are provided within parenthesis for each major taxon.

\section{PAPILIONOIDEA(138) \\ Papilionidae(4)}

Papilioninae (4)

Troidini (2)

Battus polydamas polydamas (Linnaeus, 1758)

Parides zacynthus polymetus (Godart, 1819)

Papilionini (2)

Heraclides anchisiades capys (Hübner, [1809])

Heraclides thoas brasiliensis (Rothschild \& Jordan, 1906)

\section{Pieridae (18)}

Dismorphiinae (2)

Dismorphia amphione astynome (Dalman, 1823)

Enantia lina versicolora (Fruhstorfer, 1912)

Coliadinae (11)

Anteos clorinde (Godart, [1824])

Anteos menippe (Hübner, [1818])

Aphrissa statira statira (Cramer, 1777)

Eurema agave pallida (Chavannes, 1850)

Eurema albula albula (Cramer, 1775)

Eurema elathea flavescens (Chavannes, 1850)

Eurema phiale paula (Röber, 1909)

Leucidia elvina (Godart, 1819)

Phoebis sennae marcellina (Cramer, 1777)

Phoebis philea philea (Linnaeus, 1763)

Pyrisitia nise tenella (Boisduval, 1836)

Pierinae (5)

Ascia monuste orseis (Godart, 1819)

Hesperocharis anguitia anguitia (Godart, 1819)

Itaballia demophile nimietes (Fruhstorfer, 1907)

Melete lycimnia flippantha (Fabricius, 1793)

Melete lycimnia phazania Frustorfer, 1907

\section{Lycaenidae (17)}

Polyommatinae (3)

Hemiargus hanno hanno (Stoll, 1790)

Leptotes cassius cassius (Cramer, 1775)

Zizula cyna (Edwards, 1881)

Theclinae (14)

Allosmaitia strophius (Godart, [1824])

Arawacus euptychia (Draudt, 1920)

Calycopis caulonia (Hewitson, 1877)

Electrostrymon endymion (Fabricius, 1775) 
Parrhasius polibetes (Stoll, 1781)

Rekoa palegon (Cramer, 1780)

Strymon astiocha (Prittwitz, 1865)

Strymon bubastus (Stoll, 1780)

Strymon crambusa (Hewitson, 1874)

Strymon mulucha (Hewitson, 1867)

Strymon rufofusca (Hewitson, 1877)

Strymon ziba (Hewitson, 1868)

Theritas hemon (Cramer, 1775)

Ziegleria syllis (Godman \& Salvin, 1887)

\section{Riodinidae (12)}

Mesosemiini (3)

Ionotus alector (Geyer, 1837)

Perophthalma tullius (Fabricius, 1787)

Voltinia sp.

Eurybiini (1)

Eurybia pergaea (Geyer, 1832)

Riodinini (5)

Baeotis hisbon (Cramer, 1775)

Calephelis braziliensis McAlpine, 1971

Melanis smithiae (Westwood, 1851)

Melanis xenia xenia (Hewitson, [1853])

Parcella amarynthina (C. Felder \& R. Felder, 1865)

Nymphidiini (2)

Aricoris campestris (H.W. Bates, 1868)

Synargis calyce (C. Felder \& R. Felder, 1862)

Incertae sedis (1)

Emesis diogenia Prittwitz, 1865

\section{Nymphalidae}

(87)

Danainae (18)

Danaini (4)

Lycorea halia discreta Haensch, 1909

Danaus gilippus gilippus (Cramer, 1775)

Danaus erippus (Cramer, 1775)

Danaus eresimus plexaure (Godart, 1819)

Ithomiini (14)

Callithomia lenea (Cramer, 1779)

Dircenna dero celtina Burmeister, 1878

Episcada clausina (Hewitson, 1876)

Episcada hymenaea (Prittwitz, 1865)

Heterosais edessa (Hewitson, [1855])

Hypothyris ninonia daetina (Weymer, 1899)

Ithomia agnosia Hewitson, [1855]

Ithomia drymo Hübner, 1816 
Mechanitis lysimnia nesaea Hübner, [1820]

Methona singularis (Staudinger, [1884])

Napeogenes inachia ssp.

Pseudoscada erruca (Hewitson, 1855)

Scada karschina delicata Talbot, 1932

Scada reckia reckia (Hübner, [1808])

Satyrinae (23)

Morphini (1)

Morpho helenor anakreon Fruhstorfer, 1910

Brassolini (6)

Caligo illioneus illioneus (Cramer, 1775)

Caligo teucer ssp.

Eryphanis automedon (Cramer, 1775)

Eryphanis reevesii reevesii (Doubleday, [1849])

Opsiphanes cassiae crameri C. Felder \& R. Felder, 1862

Opsiphanes invirae remoliatus Fruhstorfer, 1907

Haeterini (1)

Pierella lamia ssp.

Satyrini (15)

Chloreuptychia arnaca (Fabricius, 1776)

Cissia myncea (Cramer, 1780)

Hermeuptychia atalanta (Butler, 1867)

Magneyptychia libye (Linnaeus, 1767)

Pareuptychia ocirrhoe interjecta (D'Almeida, 1952)

Pareuptychia hesionides Forster, 1964

Paryphthimoides poltys (Prittwitz, 1865)

Pharneuptychia sp.

Taygetis laches laches (Fabricius, 1793)

Taygetis sosis Hopffer, 1874

Taygetis virgilia (Cramer, 1776)

Yphthimoides ochracea (Butler, 1867)

Yphthimoides renata (Stoll, 1780)

Yphthimoides affinis (Butler, 1867)

Yphthimoides manasses (C. Felder \& R. Felder, 1867)

Charaxinae (7)

Aneini (4)

Fountainea ryphea phidile (Geyer, 1837)

Memphis acidalia (Hübner, [1819])

Memphis leonida editha (Comstock, 1961)

Zaretis sp.

Preponini (3)

Archaeoprepona amphimachus amphimachus (Fabricius, 1775)

Archaeoprepona demophon thalpius (Hübner, [1814])

Archaeoprepona demophoon antimache (Hübner, [1819]) 
Biblidinae (17)

Biblis hyperia (Cramer, 1779)

Callicore pygas cyllene (Doubleday, [1847])

Diaethria clymena janeira (C. Felder, 1862)

Dynamine agacles agacles (Dalman, 1823)

Dynamine athemon athemaena (Hübner, [1824])

Dynamine postverta postverta (Cramer, 1779)

Dynamine tithia tithia (Hübner, [1823])

Ectima thecla thecla (Fabricius, 1796)

Hamadryas amphinome amphinome (Linnaeus, 1767)

Hamadryas arete (Doubleday, 1847)

Hamadryas epinome (C. Felder \& R. Felder, 1867)

Hamadryas februa februa (Hübner, [1823])

Hamadryas feronia feronia (Linnaeus, 1758)

Hamadryas iphthime iphthime (Bates, 1864)

Mestra dorcas hypermestra Hübner, [1825]

Myscelia orsis (Drury, 1782)

Pyrrhogyra neaerea susarion Fruhstorfer, 1912

Cyrestinae (1)

Marpesia chiron marius (Cramer, 1779)

Nymphalinae (10)

Coeini (2)

Colobura dirce dirce (Linnaeus, 1758)

Historis odius dious Lamas, 1995

Nymphalini (1)

Vanessa myrinna (Doubleday, 1849)

Kallimini (5)

Anartia amathea ssp.

Anartia jatrophae jatrophae (Linnaeus, 1763)

Hypolimnas misippus (Linnaeus, 1764)

Junonia evarete evarete (Cramer, 1779)

Siproeta stelenes meridionalis (Fruhstorfer, 1909)

Melitaeini (2)

Ortilia ithra (W.F. Kirby, 1900)

Tegosa claudina (Eschscholtz, 1821)

Limenitidinae (1)

Adelpha cytherea aea (C.Felder \& R.Felder,1867)

Heliconiinae (10)

Argynnini (1)

Euptoieta hegesia meridiania Stichel, 1938

Acraeini (1)

Actinote pellenea auloeda Oberthür, 1917

Heliconniini (8)

Agraulis vanillae maculosa (Stichel, [1908]) 
Appendix I. Continued...

Dryadula phaetusa (Linnaeus, 1758)

Dryas iulia alcionea (Cramer, 1779)

Dione juno juno (Cramer, 1779)

Eueides isabella dianasa (Hübner, [1806])

Heliconius erato phyllis (Fabricius, 1775)

Heliconius ethilla flavomaculatus Weymer, 1894

Heliconius sara apseudes (Hübner, [1813])

HESPERIOIDEA- Hesperiidae (59)

Pyrginae (32)

Eudamini (17)

Aguna asander asander (Hewitson, 1867)

Astraptes anaphus anaphus (Cramer, 1777)

Astraptes fulgerator fulgerator (Walch, 1775)

Autochton neis (Geyer, 1832)

Autochton zarex (Hübner, 1818)

Celaenorrhinus sp.

Chioides catillus catillus (Cramer, 1779)

Phanus australis L. D. Miller, 1965

Urbanus dorantes dorantes (Stoll, 1790)

Urbanus doryssus doryssus (Swainson, 1831)

Urbanus procne (Plötz, 1880)

Urbanus pronta Evans, 1952

Urbanus proteus proteus (Linnaeus, 1758)

Urbanus simplicius (Stoll1, 1790)

Urbanus tanna Evans, 1952

Urbanus teleus (Hübner, 1821)

Urbanus velinus (Plötz, 1880)

Pyrgini (15)

Anisochoria pedaliodina extincta Hayward, 1933

Cogia calchas (Herrich-Schäffer, 1869)

Ebrietas anacreon anacreon (Staudinger, 1876)

Gorgythion begga begga (Prittwitz, 1868)

Helias phalaenoides palpalis (Latreille, [1824])

Heliopetes alana (Reakirt, 1868)

Heliopetes arsalte (Linnaeus, 1758)

Heliopetes macaira orbigera (Mabille, 1888)

Heliopetes omrina (Butler, 1870)

Nisoniades macarius (Herrich-Schäffer, 1870)

Nisoniades sp.

Pyrgus orcus (Stoll, 1780)

Quadrus cerialis (Stoll, 1782)

Timochares trifasciata trifasciata (Hewitson, 1868)

Viola violella (Mabille, 1898) 
Appendix I. Continued..

Hesperiinae (27)

Arotis sirene Mabille, 1904

Callimormus corus Bell, 1941

Calpodes ethlius (Stoll, 1782)

Corticea corticea (Plötz, 1882)

Cymaenes laureolus loxa Evans, 1955

Cynea diluta (Herrich-Schäffer, 1869)

Hylephila phyleus phyleus (Drury, 1773)

Lucida sp.

Mnasilus allubita (Butler, 1877)

Nastra chao (Mabille, 1898)

Neoxeniades braesia aqua Evans, 1955

Nyctelius nyctelius nyctelius (Latreille, [1824])

Panoquina lucas (Fabricius, 1793)

Perichares philetes adela (Hewitson, 1867)

Polites vibex catilina (Plötz, 1886)

Pompeius amblyspila (Mabille, 1898)

Pompeius pompeius (Latreille, [1824])

Quinta cannae (Herrich-Schäffer, 1869)

Saliana longirostris (Sepp, [1840])

Saliana triangularis (Kaye, 1914)

Synapte malitiosa equa Evans, 1955

Thracides phidon (Cramer, 1779)

Vehilius stictomenes stictomenes (Butler, 1877)

Vettius artona (Hewitson, 1868)

Vettius phyllus prona Evans, 1955

Wallengrenia otho ssp.

Wallengrenia premnas (Wallengren, 1860) 